\title{
$\begin{array}{ll}\text { Research Square } & \begin{array}{l}\text { Preprints are preliminary reports that have not undergone peer review. } \\ \text { They should not be considered conclusive, used to inform clinical practice, } \\ \text { or referenced by the media as validated information. }\end{array}\end{array}$
}

\section{Have Progestin Related and Sporadic High Grade Meningiomas the Same Natural History?}

Antoine Devalckeneer ( $\nabla$ antoine.devalckeneer@gmail.com )

Université de Lille: Universite de Lille https://orcid.org/0000-0002-6111-3768

Rabih Aboukais

CHRU de Lille Neurochirurgie: Centre Hospitalier Regional Universitaire de Lille Neurochirurgie

Maxime Faisant

CHRU de Lille Neurochirurgie: Centre Hospitalier Regional Universitaire de Lille Neurochirurgie

Philippe Bourgeois

CHRU de Lille Neurochirurgie: Centre Hospitalier Regional Universitaire de Lille Neurochirurgie

Vannod-Michel Quentin

CHRU de Lille Neurochirurgie: Centre Hospitalier Regional Universitaire de Lille Neurochirurgie

Fabienne Escande

CHRU de Lille Neurochirurgie: Centre Hospitalier Regional Universitaire de Lille Neurochirurgie

Claude-Alain Maurage

CHRU de Lille Neurochirurgie: Centre Hospitalier Regional Universitaire de Lille Neurochirurgie Jean-Paul Lejeune MD

CHRU de Lille Neurochirurgie: Centre Hospitalier Regional Universitaire de Lille Neurochirurgie

\section{Research Article}

Keywords: high grade meningioma, progestin related meningiomas, cyproterone acetate, nomegestrol acetate, chlormadinone acetate

Posted Date: July 9th, 2021

DOI: https://doi.org/10.21203/rs.3.rs-680956/v1

License: (c) (7) This work is licensed under a Creative Commons Attribution 4.0 International License. Read Full License 


\section{Abstract}

Introduction: High grade progestin related meningiomas have been reported in recent series but we found no previous study describing their long-term outcome. Our study aimed to evaluate patients operated on for high grade intracranial meningioma and who underwent long term exposure to high dose of cyproterone acetate, nomegestrol acetate and chlormadinone acetate.

Methods: Our study retrospectively included 9 patients with high grade progestin related intracranial meningioma between December 2006 and December 2020. In each patient, clinico-radiological follow-up was performed every 6 months after diagnosis and treatment withdrawal recommendation.

Results: The mean progestative exposure was 11.4 years. Edema existence or absence of cleft sign on MRI were the key factors for surgical indication. All patients underwent surgery. Ajduvant radiotherapy was indicated in 1 patient, and Gamma Knife Radiosurgery was proposed in 2 other patients for a second location of mengioma. 6 patients harbored a grade II chordoïd meningioma subtype with $100 \%$ PR expression and 3 patients a grade II atypical meningioma subtype with lower PR expression. The mean follow-up was 7.1 years and none of the 9 patients presented with a recurrence.

Conclusion: Patients with Grade II progestin related meningiomas have less tumor recurrence after surgery than patients with sporadic high grade meningomas, especially after progestin withdrawal. The presence/ appearance of peri-meningioma edema and the absence of cleft sign before volumetric change should suggest the existence of an underlying high grade meningioma. In these cases, surgical resection may immediately be considered and adjuvant radiotherapy should be reserved for proven recurrence cases.

\section{Introduction}

Intracranial meningiomas are extra-axial tumors arising from arachnoid tissue. Meningiomas are the most frequent primary tumors and are in most cases benign (grade I according to 2016 WHO's classification). In 2007, Gazerri and al. [1] published the first case of growing meningioma under feminizing endocrine regimen of ethinyl estradiol and cyproterone acetate (CA) in a transsexual patient. Several reports[1-23] have documented an increased risk of meningioma development in patients with long term progestative treatment but causal relationship remains difficult to prove. Similarly, some authors reported a relationship between long term nomegestrol acetate $(\mathrm{NA})[8,13,24-26]$ or chlormadinone acetate $(\mathrm{ChI} A)[13,15,25,27]$ treatment and meningioma development. Meningioma regression after CA withdrawal is reported by many authors[2-5, 7-10, 12-15, 19, 21-24, 26, 28] in one third of cases especially for anterior and middle skull base locations. This feature and a higher rate of multiple meningiomas suggest a strong relationship between this hormonal treatment and meningioma development. Therefore, delayed treatment of hormonal induced meningiomas with close clinical and MRI follow-up is recommended by several authors $[3,8,9,13,19,22,23,26,28]$ in asymptomatic patients. Nevertheless, this management still needs further evaluation. Despite recent publications $[9,13,15,17-19,22,27]$ in which high grade hormonal induced meningiomas were found, no study concerning their specific long-term outcome is reported. Concerning sporadic meningiomas, recent studies reported a 15-20\% rate of high grade meningioma[13, 27, 29-33]. The progression-free survival rate (PFSR) of patients harboring a sporadic grade II meningioma is approximately $50 \%$ at 5 years questioning in these cases the indication for adjuvant radiation therapy[29-31,33-35]. The optimal timing of radiation therapy after surgery is still under evaluation[34].

Our study aimed to evaluate the outcome of patients with high grade intracranial meningioma who underwent long term exposure to high dose of CA, NA and ChIA.

\section{Methods}

\section{Patients}

After ethics committee agreement, we retrospectively collected 152 consecutive adult patients with intracranial meningioma and exposed to one of the 3 progestatives incriminated in meningioma development between December 2006 and December 2020. Of the 43 patients who underwent surgery we included 9 patients with high grade meningioma.

\section{Meningioma management in our institution}

Based on previous knowledges, progestative withdrawal was always recommended to all patients after meningioma diagnosis. Observation after diagnosis was systematically performed in all asymptomatic patients (incidental finding or screening) or patients presenting with mild headache without neurological deficit, regardless tumor volume or number of tumors. All patients presenting with neurological deficit and/or with peritumoral brain edema were systematically proposed for treatment. Clinical and radiological evaluation using MRI was performed every six months then annually in each patient. During follow-up, treatment was proposed in case of evolving meningioma: symptoms, increasing volume tumor and/or appearance of peritumoral brain edema. When high grade meningioma was diagnosed, adjuvant radiation therapy was discussed according to EANO recommendations. As potential tumor potential regression was reported in patients with progestin related meningiomas, no systematic adjuvant radiotherapy was performed in our series.

\section{Clinical and radiological follow-up data collection}

Among clinical data, sex, age at diagnosis, medical history and clinical presentation were considered in each patient. Type of hormonotherapy, duration of exposure and reason for prescription were recorded. Concomitant estrogen regimen use was also registered. First MRI at diagnosis and MRI at last follow-up were compared to evaluate tumor evolution (stabilization, progression, regression and recurrence). Follow-up duration was calculated using the delay between these two exams. Number and location of each meningioma (skull base, convexity, median and other) were observed. Peritumoral brain edema existence, absence of cleft sign and volumetric meningioma evolution were documented. Type of meningioma treatment (surgery, gamma-knife radiosurgery, radiation therapy) was considered. Simpson grade were assessed on the basis of operative reports and post-operative MRI. In our clinical practice, gamma-knife 
radiosurgery (GKS) and conventional radiation therapy were reserved to inoperable cases or to adjuvant therapy for high grade meningiomas. Pathological diagnosis (according to 2016 WHO classification), hormonal receptors expression and biomolecular studies were performed in each operated patient.

PFSR was assessed on the interval between immediate post-operative MRI and last available MRI during follow-up, and presented with standard Kaplan-Meier curve. We compared our results to previously published series in which high grade sporadic and radio-induced meningiomas PFSR are documented.

\section{Results}

In this series, 9 patients underwent surgery for a progestin related high grade meningioma. The indication for hormonal treatment is summarized in Table 1. The prescribing physician was a gynecologist in 7 patients and a dermatologist in 2 patients. All patients used a continuous progestative treatment without counterbalancing estrogen therapy. Clinical findings are presented in Table 2, and radiological findings in Tables 3 and 4 . Surgical resection (Simpson grade III) of the tumor was complete in all cases but one who underwent further radiation therapy. Another patient had gamma knife radiosurgery to control a second location of meningioma. No patient died, and postoperative course was uneventful in all patients without neurological worsening. Immunohistological and biomolecular results are summarized in Table 5. With a mean follow up of 7.1 years, none of the 9 patients showed clinical or radiological signs of tumor recurrence.

\section{Discussion}

Grade II progestin related meningiomas show less tumor recurrence rate after surgery than patients with sporadic high grade meningomas, especially after progestin withdrawal. After complete surgical resection of grade II progestin related meningioma, adjuvant radiation therapy might be reserved for radiologically proven recurrence cases.

\section{High grade meningioma identification}

Based on recent publications[1-14, 19-27, 36, 37], surgical treatment of meningiomas should be proposed with caution in case of CA exposure because of potential meningioma regression after progestin withdrawal. For patients with $N A[8,13,24-26]$ and ChIA $[13,15,25,27]$ exposure, the potential tumor regression appears less significant in the literature. The potential impact of NA and ChIA on meningioma growth is probably different from CA on a biomolecular point of view. Despite these data, high grade meningioma occurred in the 3 progestin groups. In our opinion, when peritumoral brain edema is present or appears on MRI and when the cleft sign is absent, diagnosis of high grade meningiomas should be suspected even in asymptomatic patient. Moreover, in their recent study JB Pond and al. [35]suggested significant elevations in ADC and NADC values for grade II chordoid meningiomas when compared with all other WHO meningiomas subtypes. This feature may also provide reliable presurgical prediction of the histological diagnosis. Thus, when these radiologic signs are present delayed surgery is less recommended and should be performed as soon as possible in progestin related meningiomas.

\section{PFSR after surgical resection}

After surgical resection, no tumor recurrence was noted in patients with high grade hormonal induced meningiomas. This is unsual compared to patients with high grade sporadic meningioma who harbored a 50\% PFSR at 5 years (Figure 1.) In our limited series even in case of Simpson 4 extension grade resection (Patient 9), no tumor progression was noted at last follow-up. Similarly, no tumor progression was noted in the five patients with Simpson 2 extended grade resection. None of these patients underwent adjuvant radiotherapy. Based on this result and on the fact that the optimal timing use of radiation therapy remains discussed for sporadic meningiomas (i.e. ROAM-EORTC 1308[34]), radiation therapy could only be performed in case of proved tumor progression after surgical resection in patient with progestin related high grade meningiomas. Our treatment strategy is different for sporadic high grade meningiomas for which adjuvant radiation therapy is preferred, especially in case of incomplete surgical resection. The indication of radiation therapy can be debatable in Patient 3 who had a Simpson 3 extended grade resection. Gamma knife radiosurgery remained a safe and effective treatment other than surgery in patients who developed tumor progression of a second meningioma location. Tumor regression was noted in all GKS treated patients. Even if no study has identified an obvious common downstream target for determining the intracellular signaling pathways implicated in progestin induced meningiomas, antiprogesterone treatments could be interesting to propose as an alternative in case of recurrence when new surgery is refused by the patient or not applicable before proposing radiotherapy [25].

\section{MRI volumetric follow-up}

Semestrial volumetric long-term MRI follow-up is mandatory to assess tumor evolution in multiple meningiomas cases. In case of NA and ChIA exposure, other meningioma location progression was usually noted in our series despite the progestin withdrawal recommendation. On the contrary, as already demonstrated in CA exposure, regression and stabilization of the other meningioma locations appears more frequently after progestin withdrawal. The appearance of "de novo" meningioma and progression of preexisting meningiomas (Patient 5), may lead to confound a patient who is not following the withdrawal recommendation (defined as a pseudo-progression in Table 4). Indeed, some patients remain very attached to their hormonal treatment i.e. for cosmetic reasons.

\section{Hormonal receptor expression}

One argument in the meningioma development hormonal theory is sustained by the hormonal receptors expression. It is generally admitted that most meningiomas express progesterone receptors (PR) but they rarely express estrogen receptors (ER)[17, 38-41]. Low or negative PR expression and positive ER expression are more frequently seen in high grade meningiomas[17, 38-41]. In our series, all patients demonstrated hormonal receptors expression which is consistent with a progestin related meningioma theory. In our series, the high grade meningioma rate in patients with progestin related meningiomas appears higher than in patients with sporadic meningiomas. Moreover, on the contrary of patients with high grade sporadic meningiomas, grade II chordoïd 
meningiomas $(n=6)$ were more frequent than atypical meningiomas $(n=3)$. All patients with grade II chordoïd meningioma subtype harbored a maximal rate of PR expression (100\%) and only two of these patients had moderate ER expression. The 3 remaining patients with grade II atypical meningioma subtype had only a lower PR expression. Even if our results based on hormonal receptors expression should be interpreted with caution due to sample size, it is consistent with the more indolent course of high grade progestin induced meningiomas. It may partially explain that in our series no recurrence was observed in the 9 cases of high grade meningioma after the mean follow-up of 7.1 years. This difference highlights the need of systematic receptor expression study in all cases of sporadic meningioma and progestin related meningiomas.

\section{Biomolecular profile}

No concomitant estrogen regimen was performed in all patients despite actual recommendation for CA use, and concomitant estrogen regimen is not mandatory in NA and ChIA prescription. This unbalanced hormone regimen is a controversial factor of hormonal tumor development but an intriguing factor in progestin related meningioma development. In his series of 40 patients operated of meningioma and exposed to a long term progestative therapy, Peyre and al.[15] demonstrated a shift in mutational landscape indicating the vulnerability of certain meningeal cells and mutations to hormone-induced tumorigenesis. While the relationship between PIK3CA mutation frequency and hormone-related cancers (such as breast and endometrial cancers) is well-known, this hormonally induced mutational shift is a unique feature in molecular biology of progestin related meningiomas compared to sporadic meningiomas. In our series, this PIK3CA mutation was only found in 2 grade II atypical meningiomas which was consistent with Peyre and al. study who reported a lower PIK3CA mutants rate in case of high grade meningiomas. Some authors[15, 42,43] also suggest that PIK3 activation is insufficient alone to conduct to malignant meningioma transformation highligting the unknown field of progestin on meningioma tumorigenesis while reinforcing the implication of progestin in these particular cases. In line with recent reports[42,44], when PIK3CA or AKT1 mutant were identified in skull base meningioma locations in our series, no recurrence occurred during the follow-up period. NF2 mutation was found in one female patient without higher aggressivity or recurrence, comforting the mutation alone is not sufficient for malignant transformation. The other mutations interpretation is more delicate as no global consensus exists. On another point of view, the biomolecular result is consistent with the operated location[45] and probably explained by embryological reasons as suggested by some authors $[40,44,46,47]$. DNA methylation and karyotype studies might help to better understanding of meningioma tumorigenesis[29, 48-50].

\section{Limitations of our study}

The results of this series should be interpreted with caution due to the limited sample size. Further studies with more patients are required to confirm our findings. Conducting systematic biomolecular studies including methylation studies on larger cohorts and comparing it to sporadic meninongiomas could be useful to better understand intracranial meningiomas development and the mechanism of high grade transformation. Such studies may precise the impact of progestatives in the history of meningioma development and progression. This study highlights the need of a multidisciplinary prospective approach in systematic screening, and the necessity of a national or European register, especially in case of progestin induced meningiomas.

\section{Conclusion}

To our knowledge, this is the first study reporting the long-term outcome of patients with grade II progestin related meningiomas. These patients show less tumor recurrence after surgery than patients with sporadic high grade meningomas, especially when they accept the progestin withdrawal recommendation. No recurrence was noted in the 9 patients after a mean follow-up of 7.1 years. In our series, grade Il chordoïd meningiomas are more frequent than atypical meningiomas but all patients presented with high progesterone receptors expression which is consistent with hormonal exposure. The presence or appearance of peri-meningioma edema and the absence of cleft sign before volumetric change should suggest the existence of an underlying high grade meningioma. In these cases, surgical resection could be immediately considered and adjuvant radiation therapy could be reserved for proven recurrence cases despite recommendations for high grade sporadic meningioma management.

\section{Declarations}

\section{Funding none}

\section{Conflicts of interest/Competing interests none}

Ethics approval Ethical approval was waived by the local Ethics Committee of Lille University in view of the retrospective nature of the study and all the procedures being performed were part of the routine care

Consent to participate Informed consent was obtained from all individual participants included in the study

Consent for publication The authors affirm that human research participants provided informed consent for publication of the images in Figure1

Availability of data and material The datasets generated during and/or analysed during the current study are available from the corresponding author on reasonable request

\section{Code availability not applicable}

Authors' contributions All authors contributed to the study conception and design. Material preparation, data collection and analysis were performed by Antoine Devalckeneer, Rabih Aboukais and Jean-Paul Lejeune. The first draft of the manuscript was written by Antoine Devalckeneer and all authors commented on previous versions of the manuscript. All authors read and approved the final manuscript. 


\section{References}

1. Gazzeri R, Galarza M, Gazzeri G (2007) Growth of a meningioma in a transsexual patient after estrogen-progestin therapy. N Engl J Med 357: 2411-2412 doi:10.1056/NEJMc071938

2. Bergoglio MT, Gómez-Balaguer M, Almonacid Folch E, Hurtado Murillo F, Hernández-Mijares A (2013) Symptomatic meningioma induced by cross-sex hormone treatment in a male-to-female transsexual. Endocrinol Nutr 60: 264-267 doi:10.1016/j.endonu.2012.07.004

3. Bernat AL, Bonnin S, Labidi M, Aldahak N, Bresson D, Bouazza S, Froelich S (2018) Regression of Giant Olfactory Groove Meningioma and Complete Visual Acuity Recovery after Discontinuation of Cyproterone Acetate. J Ophthalmic Vis Res 13: 355-358 doi:10.4103/jovr.jovr_21_17

4. Bernat AL, Oyama K, Hamdi S, Mandonnet E, Vexiau D, Pocard M, George B, Froelich S (2015) Growth stabilization and regression of meningiomas after discontinuation of cyproterone acetate: a case series of 12 patients. Acta Neurochir (Wien) 157: 1741-1746 doi:10.1007/s00701-015-2532-3

5. Botella C, Coll G, Lemaire JJ, Irthum B (2015) [Intra cranial meningiomas and long term use of cyproterone acetate with a conventional dose in women. A report of two cases of tumor decrease after treatment withdrawal]. Neurochirurgie 61: 339-342 doi:10.1016/j.neuchi.2015.05.002

6. Cea-Soriano L, Blenk T, Wallander MA, Rodríguez LA (2012) Hormonal therapies and meningioma: is there a link? Cancer Epidemiol 36: 198-205 doi:10.1016/j.canep.2011.08.003

7. Cebula H, Pham TQ, Boyer P, Froelich S (2010) Regression of meningiomas after discontinuation of cyproterone acetate in a transsexual patient. Acta Neurochir (Wien) 152: 1955-1956 doi:10.1007/s00701-010-0787-2

8. Champagne PO, Passeri T, Froelich S (2019) Combined hormonal influence of cyproterone acetate and nomegestrol acetate on meningioma: a case report. Acta Neurochir (Wien) 161: 589-592 doi:10.1007/s00701-018-03782-4

9. Champeaux-Depond C, Weller J, Froelich S, Sartor A (2021) Cyproterone acetate and meningioma: a nationwide-wide population based study. J Neurooncol doi:10.1007/s11060-020-03672-9

10. Cheriyan S, Santoreneos S, Wells AJ (2020) Rapid growth of an atypical meningioma in association with cyproterone acetate use: Case report. J Clin Neurosci 82: 268-270 doi:10.1016/j.jocn.2020.09.053

11. Gil M, Oliva B, Timoner J, Maciá MA, Bryant V, de Abajo FJ (2011) Risk of meningioma among users of high doses of cyproterone acetate as compared with the general population: evidence from a population-based cohort study. Br J Clin Pharmacol 72: 965-968 doi:10.1111/j.1365-2125.2011.04031.x

12. Gonçalves AM, Page P, Domigo V, Méder JF, Oppenheim C (2010) Abrupt regression of a meningioma after discontinuation of cyproterone treatment. AJNR Am J Neuroradiol 31: 1504-1505 doi:10.3174/ajnr.A1978

13. Malaize H, Samoyeau T, Zanello M, Roux A, Benzakoun J, Peeters S, Zah-Bi G, Edjlali M, Tauziede-Espariat A, Dezamis E, Parraga E, Chrétien F, Varlet P, PluBureau G, Oppenheim C, Pallud J (2021) Evolution of the neurosurgical management of progestin-associated meningiomas: a 23-year single-center experience. J Neurooncol doi:10.1007/s11060-021-03696-9

14. Mancini I, Rotilio A, Coati I, Seracchioli R, Martelli V, Meriggiola MC (2018) Presentation of a meningioma in a transwoman after nine years of cyproterone acetate and estradiol intake: case report and literature review. Gynecol Endocrinol 34: 456-459 doi:10.1080/09513590.2017.1395839

15. Peyre M, Gaillard S, de Marcellus C, Giry M, Bielle F, Villa C, Boch AL, Loiseau H, Baussart B, Cazabat L, Raffin-Sanson ML, Sanson M, Kalamarides M (2018) Progestin-associated shift of meningioma mutational landscape. Ann Oncol 29: 681-686 doi:10.1093/annonc/mdx763

16. Plu-Bureau G (2019) [Should cyproterone acetate be removed from our prescriptions?]. Gynecol Obstet Fertil Senol 47: 823-824 doi:10.1016/j.gofs.2019.10.006

17. Portet S, Banor T, Bousquet J, Simonneau A, Flores M, Ingrand P, Milin S, Karayan-Tapon L, Bataille B (2020) New Insights into Expression of Hormonal Receptors by Meningiomas. World Neurosurg 140: e87-e96 doi:10.1016/j.wneu.2020.04.168

18. Portet S, Naoufal R, Tachon G, Simonneau A, Chalant A, Naar A, Milin S, Bataille B, Karayan-Tapon L (2019) Histomolecular characterization of intracranial meningiomas developed in patients exposed to high-dose cyproterone acetate: an antiandrogen treatment. Neurooncol Adv 1: vdz003 doi:10.1093/noajnl/vdz003

19. Samarut E, Lugat A, Amelot A, Scharbarg E, Hadjadj S, Primot C, Loussouarn D, Thillays F, Buffenoir K, Cariou B, Drui D, Roualdes V (2021) Meningiomas and cyproterone acetate: a retrospective, monocentric cohort of 388 patients treated by surgery or radiotherapy for intracranial meningioma. $\mathrm{J}$ Neurooncol doi:10.1007/s11060-020-03683-6

20. Schmutz JL (2018) [Cyproterone acetate and meningioma: The latest findings]. Ann Dermatol Venereol 145: 390-391 doi:10.1016/j.annder.2018.04.001

21. Sys C, Kestelyn P (2015) Unilateral proptosis and blindness caused by meningioma in a patient treated with cyproterone acetate. GMS Ophthalmol Cases 5: Doc05 doi:10.3205/oc000027 
22. Weill A, Nguyen P, Labidi M, Cadier B, Passeri T, Duranteau L, Bernat AL, Yoldjian I, Fontanel S, Froelich S, Coste J (2021) Use of high dose cyproterone acetate and risk of intracranial meningioma in women: cohort study. BMJ 372: n37 doi:10.1136/bmj.n37

23. Zairi F, Aboukais R, LE Rhun E, Marinho P, Maurage CA, Lejeune JP (2017) Close follow-up after discontinuation of cyproterone acetate: a possible option to defer surgery in patients with voluminous intracranial meningioma. J Neurosurg Sci 61: 98-101 doi:10.23736/S0390-5616.16.03243-4

24. AbiJaoude S, Marijon P, Roblot P, Tran S, Cornu P, Kalamarides M, Peyre M (2021) Sustained growth of intraosseous hormone-associated meningiomas after cessation of progestin therapy. Acta Neurochir (Wien) doi:10.1007/s00701-021-04781-8

25. Apra C, Roblot P, Alkhayri A, Le Guerinel C, Polivka M, Chauvet D (2020) Female gender and exogenous progesterone exposition as risk factors for sphenoorbital meningiomas. J Neurooncol 149: 95-101 doi:10.1007/s11060-020-03576-8

26. Passeri T, Champagne PO, Bernat AL, Hanakita S, Salle H, Mandonnet E, Froelich S (2019) Spontaneous regression of meningiomas after interruption of nomegestrol acetate: a series of three patients. Acta Neurochir (Wien) 161: 761-765 doi:10.1007/s00701-019-03848-x

27. Roux A, Tauziede-Espariat A, Zanello M, Gareton A, Malaize H, Benzakoun J, Zah-Bi G, Oppenheim C, Plu-Bureau G, Chretien F, Pallud J (2020) Symptomatic progestin-associated atypical grade II meningioma. A first case report. Neurochirurgie 66: 174-178 doi:10.1016/j.neuchi.2019.12.013

28. Alderman CP (2016) Probable Drug-Related Meningioma Detected During the Course of Medication Review Services. Consult Pharm 31: $500-504$ doi:10.4140/TCP.n.2016.500

29. Peyre M, Gauchotte G, Giry M, Froehlich S, Pallud J, Graillon T, Bielle F, Cazals-Hatem D, Varlet P, Figarella-Branger D, Loiseau H, Kalamarides M (2018) De novo and secondary anaplastic meningiomas: a study of clinical and histomolecular prognostic factors. Neuro Oncol 20: 1113-1121 doi:10.1093/neuonc/nox231

30. Aboukais R, Zairi F, Le Rhun E, Lejeune JP, Devos P, Reyns N (2015) Radiation-associated grade 2 meningiomas: A nine patient-series and review of the literature. Clin Neurol Neurosurg 136: 10-14 doi:10.1016/j.clineuro.2015.05.022

31. Aboukais R, Zairi F, Lejeune JP, Le Rhun E, Vermandel M, Blond S, Devos P, Reyns N (2015) Grade 2 meningioma and radiosurgery. J Neurosurg 122: 11571162 doi:10.3171/2014.9.JNS14233

32. Gill CM, Loewenstern J, Rutland JW, Arib H, Francoeur N, Wang YC, Fishman N, Pain M, Umphlett M, Kinoshita Y, McBride RB, Bederson J, Donovan M, Smith M, Sebra R, Shrivastava RK, Fowkes M (2020) Recurrent IDH mutations in high-grade meningioma. Neuro Oncol 22: $1044-1045$ doi:10.1093/neuonc/noaa065

33. Aboukais R, Baroncini M, Zairi F, Reyns N, Lejeune JP (2013) Early postoperative radiotherapy improves progression free survival in patients with grade 2 meningioma. Acta Neurochir (Wien) 155: 1385-1390; discussion 1390 doi:10.1007/s00701-013-1775-0

34. Jenkinson MD, Javadpour M, Haylock BJ, Young B, Gillard H, Vinten J, Bulbeck H, Das K, Farrell M, Looby S, Hickey H, Preusser M, Mallucci CL, Hughes D, Gamble C, Weber DC (2015) The ROAM/EORTC-1308 trial: Radiation versus Observation following surgical resection of Atypical Meningioma: study protocol for a randomised controlled trial. Trials 16: 519 doi:10.1186/s13063-015-1040-3

35. Pond JB, Morgan TG, Hatanpaa KJ, Yetkin ZF, Mickey BE, Mendelsohn DB (2015) Chordoid Meningioma: Differentiating a Rare World Health Organization Grade II Tumor from Other Meningioma Histologic Subtypes Using MRI. AJNR Am J Neuroradiol 36: 1253-1258 doi:10.3174/ajnr.A4309

36. Champeaux-Depond C, Weller J, Froelich S, Sartor A (2021) Cyproterone acetate and meningioma: a nationwide-wide population based study. J Neurooncol 151: 331-338 doi:10.1007/s11060-020-03672-9

37. Gruber CJ, Huber JC (2003) Differential effects of progestins on the brain. Maturitas 46 Suppl 1: S71-75 doi:10.1016/j.maturitas.2003.09.021

38. Omulecka A, Papierz W, Nawrocka-Kunecka A, Lewy-Trenda I (2006) Immunohistochemical expression of progesterone and estrogen receptors in meningiomas. Folia Neuropathol 44: 111-115

39. Wolfsberger S, Doostkam S, Boecher-Schwarz HG, Roessler K, van Trotsenburg M, Hainfellner JA, Knosp E (2004) Progesterone-receptor index in meningiomas: correlation with clinico-pathological parameters and review of the literature. Neurosurg Rev 27: 238-245 doi:10.1007/s10143-004-0340-y

40. Bouillot P, Pellissier JF, Devictor B, Graziani N, Bianco N, Grisoli F, Figarella-Branger D (1994) Quantitative imaging of estrogen and progesterone receptors, estrogen-regulated protein, and growth fraction: immunocytochemical assays in 52 meningiomas. Correlation with clinical and morphological data. $\mathrm{J}$ Neurosurg 81: 765-773 doi:10.3171/jns.1994.81.5.0765

41. Goffin J (1986) Estrogen- and progesterone-receptors in meningiomas. Review article. Clin Neurol Neurosurg 88: 169-175 doi:10.1016/s0303$8467(86) 80024-5$

42. Youngblood MW, Miyagishima DF, Jin L, Gupte T, Li C, Duran D, Montejo JD, Zhao A, Sheth A, Tyrtova E, Özduman K, lacoangeli F, Peyre M, Boetto J, Pease M, Avşar T, Huttner A, Bilguvar K, Kilic T, Pamir MN, Amankulor N, Kalamarides M, Erson-Omay EZ, Günel M, Moliterno J (2020) Associations of Meningioma Molecular Subgroup and Tumor Recurrence. Neuro Oncol doi:10.1093/neuonc/noaa226 
43. Peyre M, Kalamarides M (2018) Molecular genetics of meningiomas: Building the roadmap towards personalized therapy. Neurochirurgie $64: 22-28$ doi:10.1016/j.neuchi.2014.06.007

44. Youngblood MW, Günel M (2020) Molecular genetics of meningiomas. Handb Clin Neurol 169: 101-119 doi:10.1016/B978-0-12-804280-9.00006-8

45. Karsy M, Azab MA, Abou-Al-Shaar H, Guan J, Eli I, Jensen RL, Ormond DR (2018) Clinical potential of meningioma genomic insights: a practical review for neurosurgeons. Neurosurg Focus 44: E10 doi:10.3171/2018.2.FOCUS1849

46. Huntoon K, Toland AMS, Dahiya S (2020) Meningioma: A Review of Clinicopathological and Molecular Aspects. Front Oncol 10: 579599 doi:10.3389/fonc. 2020.579599

47. Ülgen E, Bektaşoğlu PK, Sav MA, Can Ö, Danyeli AE, Hızal DB, Pamir MN, Özduman K (2019) Meningiomas Display a Specific Immunoexpression Pattern in a Rostrocaudal Gradient: An Analysis of 366 Patients. World Neurosurg 123: e520-e535 doi:10.1016/j.wneu.2018.11.201

48. Sievers P, Sill M, Blume C, Tauziede-Espariat A, Schrimpf D, Stichel D, Reuss DE, Dogan H, Hartmann C, Mawrin C, Hasselblatt M, Stummer W, Schick U, Hench J, Frank S, Ketter R, Schweizer L, Schittenhelm J, Puget S, Brandner S, Jaunmuktane Z, Küsters B, Abdullaev Z, Pekmezci M, Snuderl M, Ratliff M, Herold-Mende C, Unterberg A, Aldape K, Ellison DW, Wesseling P, Reifenberger G, Wick W, Perry A, Varlet P, Pfister SM, Jones DTW, von Deimling A, Sahm F, Meningiomas" GCA (2021) Clear cell meningiomas are defined by a highly distinct DNA methylation profile and mutations in SMARCE1. Acta Neuropathol 141: 281-290 doi:10.1007/s00401-020-02247-2

49. Tang M, Wei H, Han L, Deng J, Wang Y, Yang M, Tang Y, Guo G, Zhou L, Tong A (2017) Whole-genome sequencing identifies new genetic alterations in meningiomas. Oncotarget 8: 17070-17080 doi:10.18632/oncotarget.15043

50. Sahm F, Schrimpf D, Stichel D, Jones DTW, Hielscher T, Schefzyk S, Okonechnikov K, Koelsche C, Reuss DE, Capper D, Sturm D, Wirsching HG, Berghoff AS, Baumgarten P, Kratz A, Huang K, Wefers AK, Hovestadt V, Sill M, Ellis HP, Kurian KM, Okuducu AF, Jungk C, Drueschler K, Schick M, Bewerunge-Hudler M, Mawrin C, Seiz-Rosenhagen M, Ketter R, Simon M, Westphal M, Lamszus K, Becker A, Koch A, Schittenhelm J, Rushing EJ, Collins VP, Brehmer S, Chavez L, Platten M, Hänggi D, Unterberg A, Paulus W, Wick W, Pfister SM, Mittelbronn M, Preusser M, Herold-Mende C, Weller M, von Deimling A (2017) DNA methylationbased classification and grading system for meningioma: a multicentre, retrospective analysis. Lancet Oncol 18: 682-694 doi:10.1016/S1470-2045(17)301559

\section{Tables}

Table 1. Prescriptions data

\begin{tabular}{|c|c|c|c|c|c|c|}
\hline Patients & Progestative & Daily dose & Regimen & Exposition (Y) & Estrogen & Indication \\
\hline 1 & $\mathrm{CA}$ & $50 \mathrm{mg} \mathrm{2x/d}$ & Continous & 16 & No & Hirsustim \\
\hline 2 & $\mathrm{CA}$ & $50 \mathrm{mg} 1 \mathrm{x} / \mathrm{d}$ & Continous & 3 & No & Acnea \\
\hline 3 & $\mathrm{CA}$ & $50 \mathrm{mg} 1 \mathrm{x} / \mathrm{d}$ & Continous & 15 & No & Acnea \\
\hline 4 & $\mathrm{CA}$ & $50 \mathrm{mg} \mathrm{2x/d}$ & Continous & 20 & No & Hirsutim \\
\hline 5 & $\mathrm{CA}$ & $50 \mathrm{mg} \mathrm{2x/d}$ & Continous & 19 & No & Hirsutism \\
\hline 6 & NA & $5 \mathrm{mg} 1 \mathrm{x} / \mathrm{d}$ & Continous & 7 & No & Uterine fibromas \\
\hline 7 & NA & $5 \mathrm{mg} 1 \mathrm{x} / \mathrm{d}$ & Continous & 10 & No & Uterine fibromas \\
\hline 8 & $\mathrm{CA}$ & $50 \mathrm{mg} \mathrm{2x/d}$ & Continous & 10 & No & Hirsutism \\
\hline 9 & ChIA & $10 \mathrm{mg} 1 \mathrm{x} / \mathrm{d}$ & Continous & 3 & No & Estrus cycle trouble \\
\hline
\end{tabular}

$\mathrm{CA}=$ Cyproterone Acetate

$\mathrm{NA}=$ Normegestrol Acetate

ChIA = Chlormadinone Acetate

$\mathrm{Y}=$ years

Table 2. Clinical data 


\begin{tabular}{|c|c|c|c|c|c|c|c|c|}
\hline Patients & Sex & $\begin{array}{l}\text { Age at diagnosis } \\
\text { (years) }\end{array}$ & $\begin{array}{l}\text { F/U } \\
\text { (years) }\end{array}$ & $\begin{array}{l}\text { Clinical } \\
\text { presentation }\end{array}$ & $\begin{array}{l}\text { Treatment indication conducting } \\
\text { to surgery }\end{array}$ & $\begin{array}{l}\text { Simpson } \\
\text { grade }\end{array}$ & $\begin{array}{l}\text { Adjuvant } \\
\text { Radiotherapy }\end{array}$ & $\begin{array}{l}\text { Further GKS } \\
\text { treatment }\end{array}$ \\
\hline 1 & $\mathrm{~F}$ & 50 & 12 & Headache & $\begin{array}{l}\text { Focal deficit / Edema apparition at } \\
3 \text { years } \mathrm{f} / \mathrm{u}\end{array}$ & 2 & No & No \\
\hline 2 & $\mathrm{~F}$ & 19 & 6 & $\begin{array}{l}\text { Visual } \\
\text { impairement }\end{array}$ & Focal deficit/ Edema at diagnosis & 1 & No & No \\
\hline 3 & $\mathrm{~F}$ & 47 & 6 & Seizure & Seizure/Edema at diagnosis & 3 & Yes & No \\
\hline 4 & $\mathrm{~F}$ & 63 & 9 & Seizure & Seizure/Edema at diagnosis & 2 & No & Yes \\
\hline 5 & $\mathrm{~F}$ & 38 & 13 & $\begin{array}{l}\text { Comportemental } \\
\text { change }\end{array}$ & Edema apparition at 6 months $\mathrm{f} / \mathrm{u}$ & 2 & No & Yes \\
\hline 6 & $\mathrm{~F}$ & 54 & 6 & Focal deficit & Focal deficit/ Edema at diagnosis & 1 & No & No \\
\hline 7 & $\mathrm{~F}$ & 64 & 4 & Headache & Edema at diagnosis & 2 & No & No \\
\hline 8 & $\mathrm{~F}$ & 28 & 4 & Headache & Edema at diagnosis & 2 & No & No \\
\hline 9 & $\mathrm{~F}$ & 45 & 4 & Headache & Edema at diagnosis & 4 & No & No \\
\hline
\end{tabular}

$\mathrm{F}=$ Female

$\mathrm{F} / \mathrm{U}=$ follow-up

GKS $=$ Gamma-knife surgery

Table 3. Radiological data of operated meningioma

\begin{tabular}{|c|c|c|c|c|c|c|c|c|c|c|c|}
\hline Patient & $\begin{array}{l}\mathrm{Nb} \\
\text { meningiomas }\end{array}$ & $\begin{array}{l}\text { Skull } \\
\text { base }\end{array}$ & Median & Convexity & $\begin{array}{l}\text { Operated } \\
\text { meningioma } \\
\text { location }\end{array}$ & $\begin{array}{l}\text { Operated } \\
\text { meningioma } \\
\text { volume } \\
\left(\mathrm{cm}^{3}\right)\end{array}$ & $\begin{array}{l}\text { Cleft } \\
\text { sign }\end{array}$ & $\begin{array}{l}\text { Peritumoral } \\
\text { brain } \\
\text { edema }\end{array}$ & $\begin{array}{l}\text { ADC } \\
\text { Aspect }\end{array}$ & $\begin{array}{l}\text { Simpson } \\
\text { grade }\end{array}$ & Reccurence \\
\hline 1 & 3 & 2 & 1 & 0 & $\begin{array}{l}\text { Rolandic } \\
\text { parasagittal }\end{array}$ & 43,5 & absent & present & Augmented & 2 & 0 \\
\hline 2 & 1 & 0 & 0 & 1 & $\begin{array}{l}\text { Parietal } \\
\text { convexity }\end{array}$ & 49,7 & absent & present & $\begin{array}{l}\text { Not } \\
\text { specific }\end{array}$ & 1 & 0 \\
\hline 3 & 1 & 0 & 0 & 1 & $\begin{array}{l}\text { Temporal } \\
\text { convexity }\end{array}$ & 23,9 & absent & present & Augmented & 1 & 0 \\
\hline 4 & 3 & 3 & 0 & 0 & $\begin{array}{l}\text { Sphenoïdal } \\
\text { extern }\end{array}$ & 38,2 & absent & present & Augmented & 2 & 0 \\
\hline 5 & 6 & 4 & 0 & 2 & $\begin{array}{l}\text { Sphenoïdal } \\
\text { jugum }\end{array}$ & 60 & absent & present & $\begin{array}{l}\text { Not } \\
\text { specific }\end{array}$ & 2 & 0 \\
\hline 6 & 9 & 5 & 0 & 4 & $\begin{array}{l}\text { Frontal } \\
\text { convexity }\end{array}$ & 61,8 & absent & present & Augmented & 1 & 0 \\
\hline 7 & 5 & 4 & 1 & 0 & $\begin{array}{l}\text { Sphenoïdal } \\
\text { extern }\end{array}$ & 104,1 & absent & present & Augmented & 2 & 0 \\
\hline 8 & 1 & 1 & 0 & 0 & $\begin{array}{l}\text { Sphenoïdal } \\
\text { extern }\end{array}$ & 107,9 & absent & present & Augmented & 2 & 0 \\
\hline 9 & 2 & 2 & 0 & 0 & Olfactive & 27,9 & absent & present & $\begin{array}{l}\text { Not } \\
\text { specific }\end{array}$ & 4 & 0 \\
\hline
\end{tabular}

$A D C=$ Apparent Diffusion Coefficient

Table 4. Radiological evolution of non-operated meningiomas and residual meningioma 


\begin{tabular}{|c|c|c|c|c|c|c|c|c|}
\hline Patients & Location & $\begin{array}{l}\text { Initial MRI } \\
\text { Volume }\left(\mathrm{cm}^{3}\right)\end{array}$ & Edema & $\begin{array}{l}\text { Last MRI } \\
\text { Volume }\left(\mathrm{cm}^{3}\right)\end{array}$ & Edema & $\begin{array}{l}\text { Qualitative } \\
\text { interpretation }\end{array}$ & F/U (years) & Progestative \\
\hline \multirow[t]{2}{*}{1} & \multirow{2}{*}{$\begin{array}{l}\text { Skull Base } \\
\text { Skull Base }\end{array}$} & 0.419 & No & 0.419 & No & Stabilization & 12 & Cyproterone \\
\hline & & 0.419 & No & 0.419 & No & Stabilization & & Acetate \\
\hline \multirow[t]{2}{*}{4} & Skull Base & 0.523 & No & 0.523 & No & Stabilization & 9 & Cyproterone \\
\hline & Skull Base & 0.523 & No & 0.523 & No & Stabilization & & Acetate \\
\hline \multirow[t]{5}{*}{5} & Skull Base ${ }^{1}$ & 1.564 & No & 0.555 & No & Pseudo-regression & 13 & Cyproterone \\
\hline & Skull Base & 0.158 & No & 0.525 & No & Pseudo-progression & & Acetate \\
\hline & Skull Base ${ }^{2}$ & Not existent & No & 1.112 & No & Pseudo-progression & & \\
\hline & Convexity & Not existent & No & 0.278 & No & Pseudo-progression & & \\
\hline & Convexity & Not existent & No & 0.245 & No & Pseudo-progression & & \\
\hline \multirow[t]{7}{*}{6} & Skull Base & 2.89 & No & 2.816 & No & Regression & 6 & Nomegestrol \\
\hline & Skull Base & 1.729 & No & 0.433 & No & Regression & & Acetate \\
\hline & Skull Base ${ }^{3}$ & 0.706 & No & 1.169 & No & Progression & & \\
\hline & Skull Base ${ }^{4}$ & 1.036 & No & 0.72 & No & Pseudo-regression & & \\
\hline & Skull Base & 0.517 & No & 0.493 & No & Regression & & \\
\hline & Convexity & 0.216 & No & 0.201 & No & Regression & & \\
\hline & Convexity & 0.186 & No & 0.092 & No & Regression & & \\
\hline \multirow[t]{3}{*}{7} & Skull Base & 1.316 & No & 1.562 & No & Progression & 4 & Nomegestrol \\
\hline & Skull Base & 8.15 & No & 8.601 & No & Progression & & Acetate \\
\hline & Median & 1.545 & No & 1.309 & No & Regression & & \\
\hline \multirow[t]{2}{*}{9} & Residue & 0.993 & No & 0.993 & No & Stabilization & 4 & Chlormadinone \\
\hline & Skull base & 0.064 & No & 0.085 & No & Progression & & Acetate \\
\hline
\end{tabular}

${ }^{1}$ Gamma-Knife Surgery (GKS) in 2011

${ }^{2}$ GKS in 2017

${ }^{3}$ GKS in 2020

${ }^{4}$ GKS in 2016

Table 5. Histopathological and biomolecular data

\begin{tabular}{|llllllll|}
\hline Patients & 2016 WHO classification & Ki67 & ER & PR & AR & Biomolecular profile & Operated locations \\
\hline $\mathbf{1}$ & Grade II choroïd & NS & negative & $100 \%$ & negative & RICTOR/FANCA & Rolandic parasagittal \\
\hline $\mathbf{2}$ & Grade II atypical & $10 \%$ & negative & $5 \%$ & negative & NF2 & Parietal convexity \\
\hline $\mathbf{4}$ & Grade II choroïd & NS & $15 \%$ & $100 \%$ & negative & AKT1 & Temporal convexity \\
\hline $\mathbf{5}$ & Grade II choroïd & NS & negative & $100 \%$ & negative & SLX4 & Sphenoïdal extern \\
\hline $\mathbf{7}$ & Grade II atypical & NS & negative & $85 \%$ & negative & PIK3CA & Sphenoïdal jugum \\
\hline $\mathbf{8}$ & Grade II choroïd & $4 \%$ & $60 \%$ & $85 \%$ & negative & 0 & Frontal convexity \\
\hline $\mathbf{9}$ & Grade II choroïd & $5 \%$ & negative & $100 \%$ & negative & 0 & Sphenoïdal extern \\
\hline
\end{tabular}

$\mathrm{ER}=$ estrogen receptors

$\mathrm{PR}=$ progesterone receptors

$\mathrm{AR}=$ androgen receptors

NS = not specified on anatomo-pathology report 
Figures

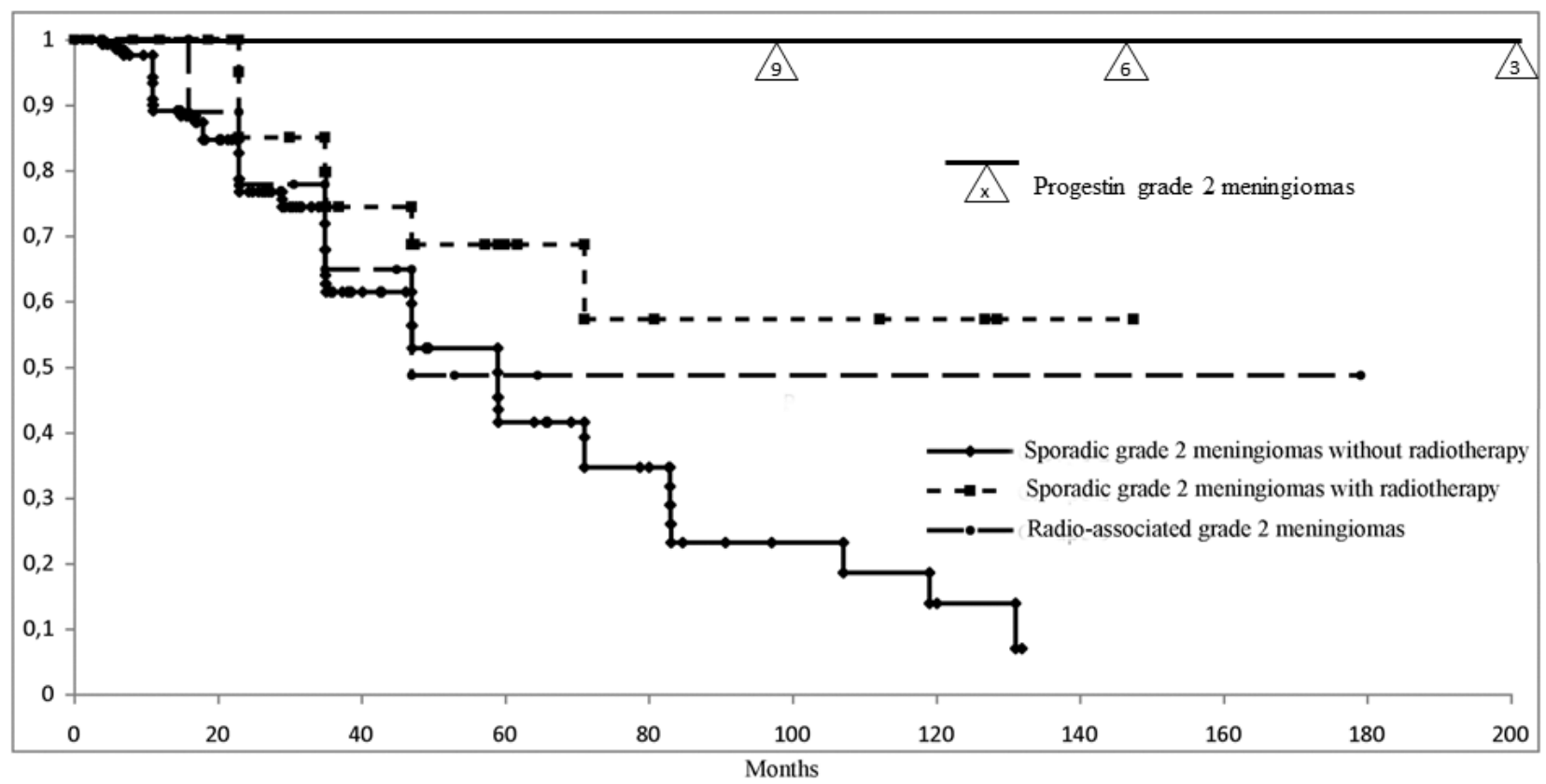

Figure 1

Progression free survival after surgery in patients with progestin related, sporadic and radiation associated grade 2 meningiomas 